\title{
The Effective Electrolytic Recovery of Dilute Copper from Industrial Wastewater
}

\author{
Teng-Chien Chen, ${ }^{1,2}$ Ricky Priambodo, ${ }^{1}$ Ruo-Lin Huang, ${ }^{1}$ and Yao-Hui Huang ${ }^{1,2}$ \\ ${ }^{1}$ Department of Chemical Engineering, National Cheng Kung University, Tainan 701, Taiwan \\ ${ }^{2}$ Sustainable Environment Research Center, National Cheng Kung University, Tainan 701, Taiwan
}

Correspondence should be addressed to Yao-Hui Huang; yhhuang@mail.ncku.edu.tw

Received 17 January 2013; Revised 19 March 2013; Accepted 19 March 2013

Academic Editor: Francesco Veglio

Copyright (C) 2013 Teng-Chien Chen et al. This is an open access article distributed under the Creative Commons Attribution License, which permits unrestricted use, distribution, and reproduction in any medium, provided the original work is properly cited.

\begin{abstract}
Electroplating copper industry was discharged huge amount wastewater and cause serious environmental and health damage in Taiwan. This research applied electrical copper recovery system to recover copper metal. In this work, electrotreatment of a industrial copper wastewater $\left([\mathrm{Cu}]=30000 \mathrm{mg} \mathrm{L}^{-1}\right)$ was studied with titanium net coated with a thin layer of $\mathrm{RuO}_{2} / \mathrm{IrO}_{2}(\mathrm{DSA})$ reactor. The optimal result for simulated copper solution was $99.9 \%$ copper recovery efficiency in current density $0.585 \mathrm{~A} / \mathrm{dm}^{2}$ and no iron ion. Due to high concentration of iron and chloride ions in real industrial wastewater, the copper recovery efficiency was down to $60 \%$. Although, the copper recovery efficiency was not high as simulated copper solution, high environmental economic value was included in the technology. The possibility of pretreating the wastewater with iron is the necessary step, before the electrical recovery copper system.
\end{abstract}

\section{Introduction}

Heavy metals are elements having atomic weights between 63.5 and $200.6 \mathrm{~g} / \mathrm{mol}$ and a specific gravity greater than 5.0 [1]. With the rapid development of industries such as metal plating facilities, mining operations, fertilizer industries, tanneries, batteries, paper industries, and pesticides, heavy metals wastewaters are directly or indirectly discharged into the environment increasingly, especially in developing countries. Unlike organic contaminants, heavy metals are not biodegradable and tend to accumulate in living organisms, and many heavy metal ions are known to be toxic or carcinogenic. Toxic heavy metals of particular concern in treatment of industrial wastewaters include nickel, mercury, cadmium, lead, and chromium.

Electroplating copper industry discharged huge amount of wastewater into wastewater plant. Copper does essential work in animal metabolism; however, the excessive ingestion of copper brings about serious toxicological concerns, such as vomiting, cramps, convulsions, or even death $[2,3]$. Due to the of complexity production processes in electroplating copper manufacturing, only acid washing water, which contains abundant cupric ions, was considered to be reclaimed here. Copper is a really rare and valuable metal. The price of copper is getting higher recently, and the production cost is increasing, and therefore it is really important to consider spent copper plating solution.

In recent years, there is an increasing interest in the development of effective electrochemical methods for the removal of metal ions from wastewaters $[4,5]$. The metal ions are effectively recovered from dilute solution using ion exchange technique, but the high cost of resin limits its application $[6,7]$; however, the electrolytic process has the advantages of metal recovery without further sequential treatment.

Electrode position has been usually applied for the recovery of metals from wastewater. It is a "clean" technology with no presence of the permanent residues for the separation of heavy metals [8]. Oztekin and Yazicigil (2006) found that electrode position is an applicable method for the recovery of metals under appropriate conditions [9]. They investigated the electrolytic recovery of metals from aqueous solutions containing complexing chelating agents such as EDTA, nitrilotriacetic acid, and citrate in a two-chamber cell separating with a commercial cation-exchange membrane. The results showed that least value of recovery of metal was approximately $40 \%$, and this value increased due to the type 
of the experiments up to $90 \%$ for copper. Chang et al. (2009a) used electro deposition in conjunction with ultrasound to reclaim EDTA-copper wastewater [10]. They found that the technique can effectively remove copper (95.6\%) and decompose EDTA (84\% COD removal) from wastewater. Issabayeva et al. (2006) [8] presented on the electro deposition of copper and lead ions onto palm shell AC electrodes. Besides, recovery of Cd and Ni by electro deposition was investigated [11].

In this study, the optimal conditions, including effect of iron concentration, effect of electric current, for electrolytic recovery of $\mathrm{Cu}^{+2}$ ions in simulated copper solution. The optimal experiment condition was applied into the real wastewater form electroplating copper industry, and also the copper recovery efficiency is evaluated in this study.

\section{Method and Materials}

2.1. Materials. The $30000 \mathrm{ppm} \mathrm{CuSO}_{4}, \mathrm{FeCl}_{3} \cdot 6 \mathrm{H}_{2} \mathrm{O}$, and $\mathrm{FeCl}_{2} \cdot 4 \mathrm{H}_{2} \mathrm{O}$ solution was purchased from Merck Company. In order to study the influence of the high organic contaminants on the recovery of copper from the raw effluent, experiments have been carried out in the synthetic effluent without any organic contaminants containing $30000 \mathrm{mgL}^{-1}$ of $\mathrm{Cu}$ in $\mathrm{H}_{2} \mathrm{SO}_{4}$. The reproducibility was checked by performing all the experiments to a minimum of at least three times.

The real industrial wastewaters were supplied form JM chemical and GW industries.

2.2. Methods. The experimental setup contains 2 plate electrodes of $18 \mathrm{~cm}(\mathrm{~L}) \times 17 \mathrm{~cm}(\mathrm{H})\left(0.039312 \mathrm{dm}^{2}\right)$ DSA net as anode and 1 plate electrode of $18 \mathrm{~cm}(\mathrm{~L}) \times 17 \mathrm{~cm}(\mathrm{H})$ $\left(0.0468 \mathrm{dm}^{2}\right)$, stainless steel as cathode. Experiments were performed with $1.4 \mathrm{~L}$ copper water solution into a $2.4 \mathrm{~L}$ acrylic electrolytic reactor tank $(20 \mathrm{~cm}(\mathrm{~L}) \times 6 \mathrm{~cm}(\mathrm{~W}) \times 20 \mathrm{~cm}(\mathrm{H}))$ with $432 \mathrm{~cm}^{2}$ effective cathode surface area. The reactor was also operated at a constant current mode. Recycling pump was also used for the mixing of the solution. The reactor was shown in Figure 1.

The electric power supply was purchased from MaxGood mechanical company (Taiwan) (Figure 2). The effluent volume of $200 \mathrm{~mL}$ was taken for all the experiments. Electrolyses were carried out as such in the raw effluent at different current density $\left(0.234,0.468,0.585\right.$, and $\left.0.702 \mathrm{~A} / \mathrm{dm}^{2}\right)$. The copper recovery efficiency effects of no iron, ferrous, and ferric ions were also evaluated in this study.

In this study, the optimal energy consumption is an important issue. It is important to spend less energy and get higher copper recovery efficiency. The specific energy consumption (EC) is calculated.

2.3. Analysis Method. All the reagents used for chemical precipitation were in industrial quality. All the preparations and experiments were done at the room temperature. All the samples were filtered with TOYO $0.45 \mu \mathrm{m}$ mixed cellulose ester filters before analysis. Concentrations of $\mathrm{Cu}$ and Fe were measured with an atomic absorption spectrophotometer (GBC Sens A), after proper pretreatment according to the instrument manufacturer's recommendations.

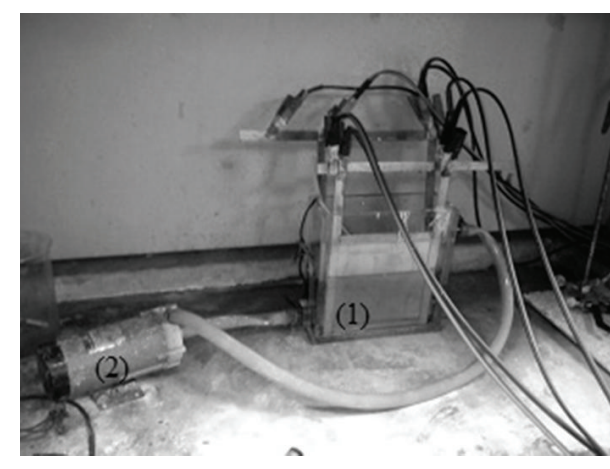

(a)

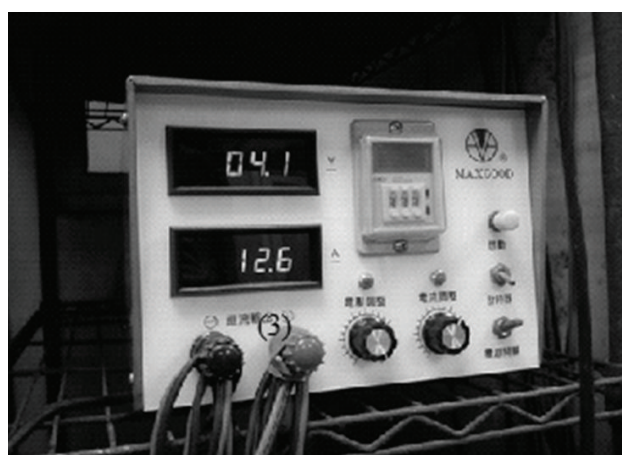

(b)

Figure 1: The electrical reactor for gold recovery (1) Double electrode cell (2) Recycling pump (3) Power supply.

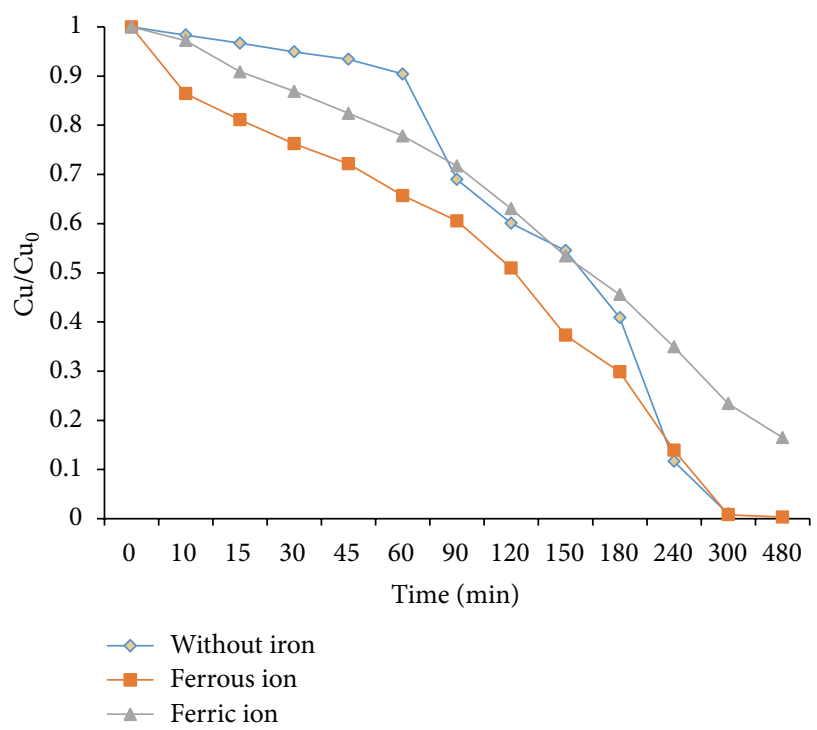

FIgURE 2: The copper reduction rate with different types of iron.

\section{Result and Discussion}

3.1. The Effect of Iron Concentration. The behavior of iron during electro-winning of copper from sulphate electrolytes is well known, and its effect on the performance of the copper electro-winning process has been reported by [12-15] who have examined the interaction of iron $\left[\mathrm{Fe}^{+2}, \mathrm{Fe}^{+3}\right]$ during 
copper electro-winning from dilute solutions, and Cooke et al. (1990) [16] who have studied the mass transfer kinetics of the ferrous-ferric system in copper sulphate electrolyte. Iron effect is an important parameter in the electrical recovery copper system. It is well known that furious is a strong transition metal catalyst, which is applied in the electrical Fenton system [17]. The ferric ion is a strong reduction catalyst; it is reduced in the electrical chemical reaction. The predominant cathode reactions during copper electrowinning from acid sulphate electrolytes can be represented by

\section{Cathode}

$$
\begin{gathered}
\text { Copper deposition : } \mathrm{Cu}^{+2}+2 \mathrm{e}^{-} \longrightarrow \mathrm{Cu} \\
\mathrm{Fe} \text { (III) reduction : } \mathrm{Fe}^{+3}+\mathrm{e}^{-} \longrightarrow \mathrm{Fe}^{+2} \\
\mathrm{Cu}+2 \mathrm{Fe}^{+3} \longrightarrow \mathrm{Cu}^{+2}+2 \mathrm{Fe}^{+2} \quad \Delta E=0.431 \mathrm{~V} \\
\text { Hydrogen evolution }: 2 \mathrm{H}_{3} \mathrm{O}^{-}+2 \mathrm{e}^{-} \longrightarrow \mathrm{H}_{2}+2 \mathrm{H}_{2} \mathrm{O} \\
\text { Anode } \\
2 \mathrm{H}_{2} \mathrm{O} \longrightarrow \mathrm{O}_{2}+4 \mathrm{H}^{+}+4 \mathrm{e}^{-} \\
\mathrm{Fe}^{+2} \longrightarrow \mathrm{Fe}^{+3}+\mathrm{e}
\end{gathered}
$$

In this research, the three different electrical copper recovery systems are evaluated. The result of copper recovery efficiency between three systems was shown in Figure 3.

Figure 3 and Table 1 showed that the copper reduction efficiency at $480 \mathrm{~min}$ reached $83.6 \%, 99.56 \%$, and $99.9 \%$ for ferric, ferrous, and without iron ions, respectively.

Reactions (1) and (2) will be mass transfer controlled during copper electrowinning. Hydrogen evolution will only occur if the cathode current density is greater than the limiting value for copper deposition. $\mathrm{Fe}^{+3}$ was conversed to $\mathrm{Fe}^{+2}$, and also copper metal was also oxidized to $\mathrm{Cu}^{+2}$. The mean effect of raising the $\mathrm{Fe}^{+3}$ concentration caused low copper reduction rate. Moreover, the adverse effect was occurred by increasing the concentration of $\mathrm{Fe}^{+3}$ in the electrical recovery copper system.

According to previous research, adding applicative concentration of $\mathrm{Fe}^{+2}$ will increase the copper recovery efficiency. In this research, different concentrations were evaluated. The result of ferrous recovery was shown in Figure 4 . Figure 4 showed that the copper removal efficiency at $300 \mathrm{~min}$ was $86.08 \%$, and $54.42 \%$ of $7.5 \mathrm{~g} / \mathrm{L}$ and $30 \mathrm{~g} / \mathrm{L}$ ferrous ion, respectively. Reactions (5) and (6) show $\mathrm{Fe}^{+2}$ to be oxidized to $\mathrm{Fe}^{+3}$ in the anode. In the cathode, the $\mathrm{Fe}^{+3}$ was reduced to $\mathrm{Fe}^{+2}$, and copper metal was oxidized to copper ion. The result indicated that the concentration of $\mathrm{Fe}^{+2}$ and $\mathrm{Fe}^{+3}$ affected the copper recovery rate in the electrical recovery copper system.

3.2. Effect of Current Density. Current density is the amount of electrical current flowing in a unit of cross-sectional area of that reactor. Current density is important to the design of electrical and electronic systems. The range of current density was applied from 0.234 to $0.702 \mathrm{Adm}^{-2}$ to make a thorough discussion. In the simulation, copper concentration

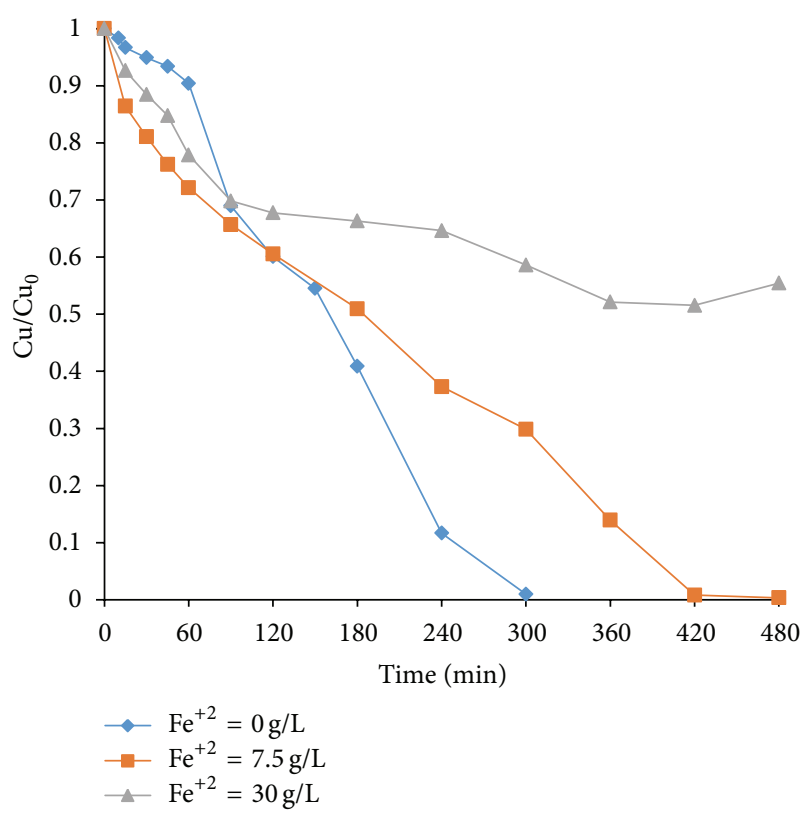

FIgURE 3: The varied for concentration of $\mathrm{Fe}^{+2}$ in the electrical copper recovery system.

TABLE 1: The copper reduction rate with different types of iron.

\begin{tabular}{lccc}
\hline \multirow{2}{*}{ Types of iron } & \multicolumn{3}{c}{ Reduction percent \% } \\
& $2 \mathrm{~h}$ & $4 \mathrm{~h}$ & $8 \mathrm{~h}$ \\
\hline Without iron & 54.8 & 99 & 99.9 \\
With ferrous ion & 39.5 & 62.8 & 99.56 \\
With ferric ion & 28.3 & 46.6 & 83.6 \\
\hline
\end{tabular}

is $30000 \mathrm{mg} / \mathrm{L}$. Figure 5 shows the changes at different current density at $\mathrm{pH} 2.5 \pm 0.3$. It is noticed that the rate of copper removal increased with the increased current density. Table 2 and Figure 5 indicated that the copper concentrations removal efficiencies were $20.97 \%, 86.08 \%, 98.80 \%$, and $99.90 \%$ for $0.234,0.468,0.585$, and $0.702 \mathrm{Adm}^{-2}$ at $360 \mathrm{~min}$, respectively. Furthermore, for a longer reaction time of $480 \mathrm{~min}$, the copper concentrations could be down to 28.54 and $19.28 \mathrm{mg} \mathrm{L}^{-1}$ for 0.585 and $0.702 \mathrm{Adm}^{-2}$, respectively. This observation is better than the results reported in the literature [18].

Depending on the solution composition of the effluent, different reactions can occur at the electrodes. In the present study, following reactions (1)-(6) would have taken place within the electrolytic cell. Due to the optimal economical reason, the current density for $0.585 \mathrm{~A} / \mathrm{dm}^{2}$ was the best condition.

3.3. The Optimal Experimental Condition. From the bench experiment, the $\mathrm{Fe}^{+2}$ and $\mathrm{Fe}^{+3}$ affected the copper recovery efficiency in the electrical recovery copper system. No iron ion effect was the best condition in this research. In the current density issue, the optimal economical reason, the current density for $0.585 \mathrm{~A} / \mathrm{dm}^{2}$ was the best condition. 

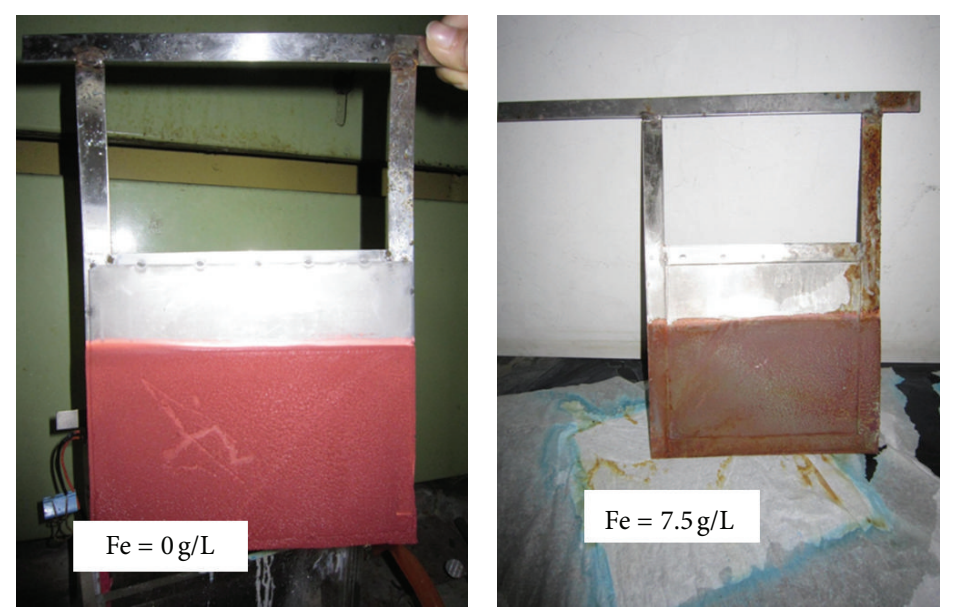

(a)

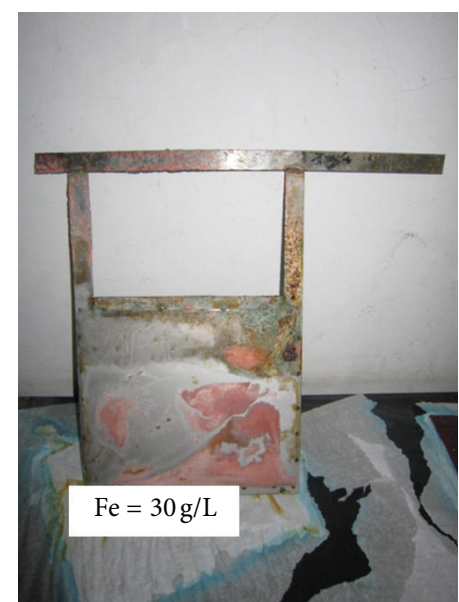

(b)

FIGURE 4: The iron effect in the electrical copper recovery system.

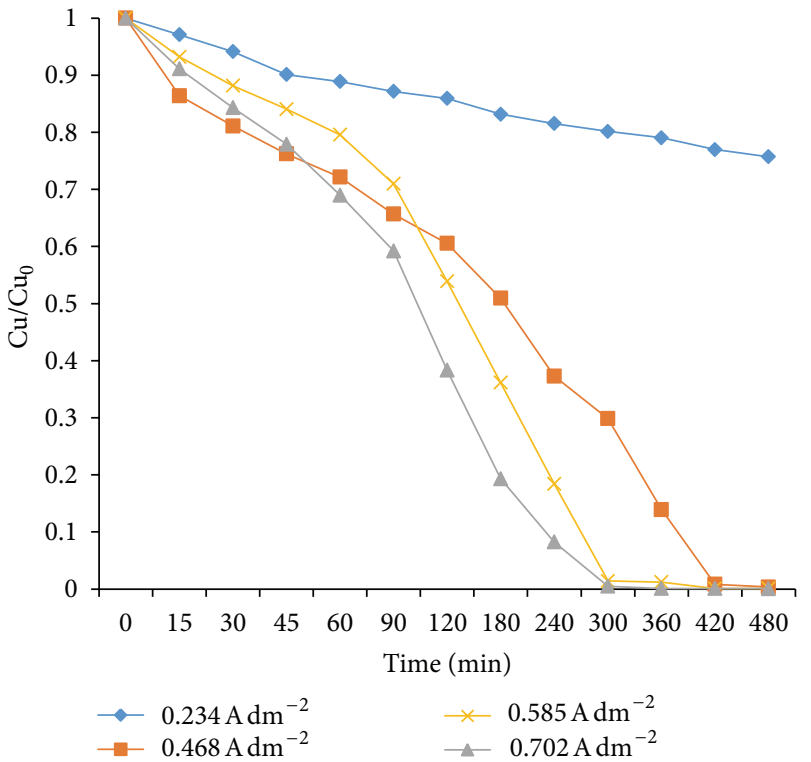

FIGURE 5: The copper recovery efficiency for different current density.

\section{Real Industrial Wastewater}

The concnetration of iron and copper ions in the wastewater were analysized by atomic absorption spectrophotometer analysis (AA). The result was shown in Table 3. Table 3 indicated that high concentrations of iron and copper were presented in this real industrial wastewater. Form the manufacture process, the raw materials for the electrical recovery copper system processes are cupric chloride and copper sulfate in the JM chemical and GW industry. Indeed, the optimal experimental conditions were applied into this real wastewater, and this research was evaluated the copper recovery efficiency.

4.1. The Copper Recovery Efficiency. Figure 6 illustrated the copper recovery efficiency between simulated copper solution and real industrial wastewater. The high copper recovery
TABLE 2: The effect of copper recovery efficiency for current density.

\begin{tabular}{lcc}
\hline Times $(\mathrm{min})$ & $\begin{array}{c}\text { Current density } \\
\left(\mathrm{A} / \mathrm{dm}^{2}\right)\end{array}$ & Copper recover ratio (\%) \\
\hline \multirow{3}{*}{360} & 0.234 & 20.97 \\
& 0.468 & 86.08 \\
& 0.585 & 98.80 \\
& 0.702 & 99.90 \\
\hline \multirow{3}{*}{480} & 0.234 & 24.29 \\
& 0.468 & 99.65 \\
& 0.585 & 99.9 \\
& 0.702 & 99.94 \\
\hline
\end{tabular}

TABLE 3: The atomic absorption spectrophotometer (AA) analysis for the Good Weld (GW) and JohgMaw (JM) industrial wastewaters.

\begin{tabular}{lcc}
\hline & {$[\mathrm{Cu}](\mathrm{ppm})$} & {$[\mathrm{Fe}](\mathrm{ppm})$} \\
\hline $\mathrm{GW}$ & 36000 & 50000 \\
$\mathrm{JM}$ & 36000 & 100000 \\
\hline
\end{tabular}

efficiency occurred, because there is no any iron effect. Table 3 indicated that the wastewater for the iron concentration in the JM chemical was two times higher than Good Weld industry. As reactions (1)-(6), copper metal is oxidized to cupper ion, when the high concentration of $\mathrm{Fe}^{+3}$ was added. The result was consistent with Das and Krishna research [19].

The chloride ion was an important factor to affect copper recovery efficiency. The electro-derived chlorine chemistry with a DC current could generate several oxidants $\left(\mathrm{Cl}_{2}\right.$, $\mathrm{HOCl}, \mathrm{OCl}^{-}$) in the presence of cupric chloride. The dissolution reactions of copper in chloride solution can be represented as $[3,5,20]$.

$$
\begin{gathered}
\text { Leach }: \mathrm{Cu}+\mathrm{Cl}_{2(\mathrm{aq})} \longrightarrow \mathrm{Cu}^{2+}+2 \mathrm{Cl}^{-} \\
\mathrm{Cu}+\mathrm{Cl}_{3}^{-} \longrightarrow \mathrm{Cu}^{2+}+3 \mathrm{Cl}^{-} \\
\mathrm{Cu}^{2+}+\mathrm{Cu} \longrightarrow 2 \mathrm{Cu}^{+}
\end{gathered}
$$




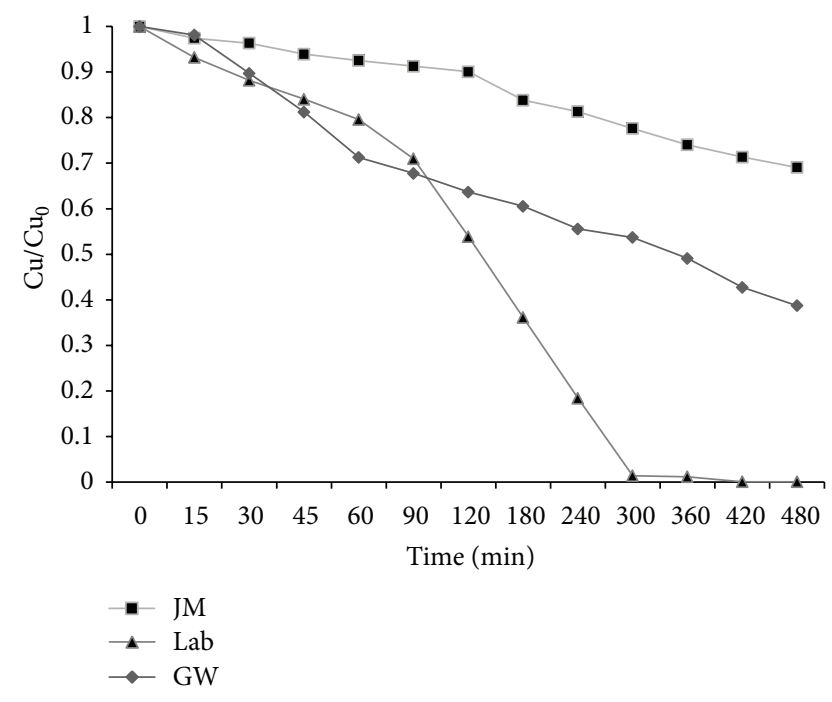

FIGURE 6: The copper recovery efficiency between simulated copper solution and the electroplating copper industry wastewater.

As a result, one mole of chlorine can oxidize two moles of copper to cuprous state by obtaining two electrons. However, when the dissolution rate of chlorine is faster than leaching rate of copper with cupric ions (9), cuprous ions are oxidized with chlorine as follows:

$$
\text { Anode }: \mathrm{Cu}^{+} \longrightarrow \mathrm{Cu}^{2+}+\mathrm{e}^{-}
$$

Due to the chloride ion effect, the low copper recovery efficiency occurred.

4.2. The Energy Consumption (EC). The specific energy consumption (EC) is calculated from the formula

$$
\mathrm{EC}=\frac{A(\mathrm{amp}) \times V(\text { volt }) \times t(\mathrm{hr}) \times 1000}{\left(C_{0}-C\right)(\mathrm{mg} / \mathrm{L}) \times V_{r}(\mathrm{~L})}
$$

where $E \cdot C$ is $\mathrm{KWh} / \mathrm{Kg}$; $A$ is operational ampere; $V$ is operational volts; $T$ is operational time; $C$ is initial concentration; $V_{r}$ is operational volume (L).

Table 4 and Figure 7 show the energy consumption for copper deposition between real industrical wastewater and simulated copper solution. The low energy consumption was around $7.03 \mathrm{KWh} / \mathrm{kg}$ for simulated copper solution in the two hours operation time. Due to complex chemical compounds for the real industrial wastewater, such as iron, high energy consumption was around $32.39 \mathrm{KWh} / \mathrm{kg}$. The low copper recovery efficiency form real industrial wastewater was gotten in the electrical recovery copper system.

\section{Conclusion}

The high copper recovery efficiency can operate for simulated copper solution at high current density $\left(0.585 \mathrm{Adm}^{-2}\right)$ and obtain copper recovery efficiency $(>99.9 \%)$. The optimum operational time and current density were around two hours and $0.585 \mathrm{Adm}^{-2}$ from simulated copper solution. In the real
TABLE 4: Evaluated the energy consumption between real industrial wastewater and simulated copper solution.

\begin{tabular}{lcccc}
\hline EC & $\begin{array}{c}2 \mathrm{~h} \\
(\mathrm{KWh} / \mathrm{kg})\end{array}$ & $\begin{array}{c}4 \mathrm{~h} \\
(\mathrm{KWh} / \mathrm{kg})\end{array}$ & $\begin{array}{c}6 \mathrm{~h} \\
(\mathrm{KWh} / \mathrm{kg})\end{array}$ & $\begin{array}{c}8 \mathrm{~h} \\
(\mathrm{KWh} / \mathrm{kg})\end{array}$ \\
\hline GW & 35.62 & 40.07 & 51.57 & 66.21 \\
$\mathrm{JM}$ & 32.39 & 58.34 & 98.59 & 137.93 \\
$\mathrm{Lab}$ & 7.03 & 8.03 & 10.02 & 13.27 \\
\hline
\end{tabular}

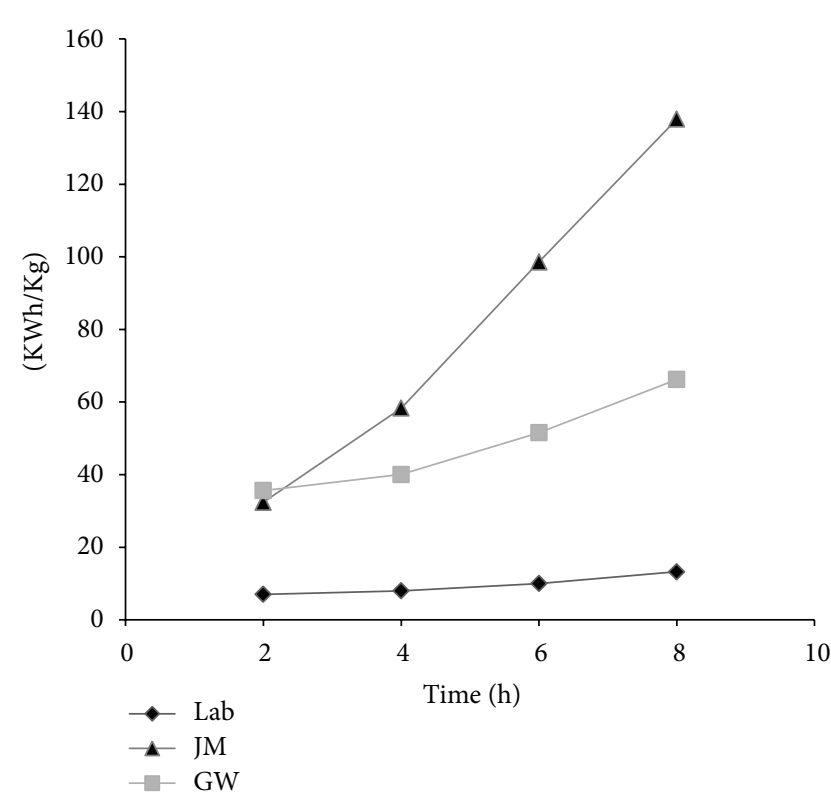

FIGURE 7: Evaluated the electrolytic recovery system in the energy consumption for copper recovery between the electroplating copper industry wastewater and simulated copper solution.

industrial wastewater, high concentration of iron reduced the copper recovery efficiency; so the high energy consumption (EC) occurred.

Although, the copper recovery efficiency was not high as simulated copper solution, high environmental economical value was included in the technology. In the future study, it is also considered that the new type reactor was capable of recovering substantial copper content from industrial wastewater. The possibility of pretreating the wastewater with iron is the necessary step, before the electrical recovery copper system.

\section{Conflict of Interests}

The authors do not have a direct financial relationship with the commercial identities mentioned in the paper that might lead to a conflict of interests.

\section{Acknowledgments}

The authors thank the Ministry of Economic Affairs of Republic of China for financial support of this research under Contract no. 101-EC-17-A-10-S1-187. 


\section{References}

[1] N. K. Srivastava and C. B. Majumder, "Novel biofiltration methods for the treatment of heavy metals from industrial wastewater," Journal of Hazardous Materials, vol. 151, no. 1, pp. 1-8, 2008.

[2] C. O. Adewunmi, W. Becker, O. Kuehnast, F. Oluwole, and G. Dörfler, "Accumulation of copper, lead and cadmium in freshwater snails in southwestern Nigeria," Science of the Total Environment, vol. 193, no. 1, pp. 69-73, 1996.

[3] A. T. Paulino, F. A. S. Minasse, M. R. Guilherme, A. V. Reis, E. C. Muniz, and J. Nozaki, "Novel adsorbent based on silkworm chrysalides for removal of heavy metals from wastewaters," Journal of Colloid and Interface Science, vol. 301, no. 2, pp. 479$487,2006$.

[4] M. Spitzer and R. Bertazzoli, "Selective electrochemical recovery of gold and silver from cyanide aqueous effluents using titanium and vitreous carbon cathodes," Hydrometallurgy, vol. 74, no. 3-4, pp. 233-242, 2004.

[5] E. Y. Kim, M. S. Kim, J. C. Lee, M. K. Jha, K. Yoo, and J. Jeong, "Effect of cuprous ions on $\mathrm{Cu}$ leaching in the recycling of waste PCBs, using electro-generated chlorine in hydrochloric acid solution," Minerals Engineering, vol. 21, no. 1, pp. 121-128, 2008.

[6] T. J. Kanzelmeyer and C. D. Adams, "Removal of copper from a metal-complex dye by oxidative pretreatment and ion exchange," Water Environment Research, vol. 68, no. 2, pp. 222$228,1996$.

[7] K. Fernando, T. Tran, S. Laing, and M. J. Kim, "The use of ion exchange resins for the treatment of cyanidation tailings Part 1Process development of selective base metal elution," Minerals Engineering, vol. 15, no. 12, pp. 1163-1171, 2002.

[8] G. Issabayeva, M. K. Aroua, and N. M. Sulaiman, "Electrodeposition of copper and lead on palm shell activated carbon in a flow-through electrolytic cell," Desalination, vol. 194, no. 1-3, pp. 192-201, 2006.

[9] Y. Oztekin and Z. Yazicigil, "Recovery of metals from complexed solutions by electrodeposition," Desalination, vol. 190, no. 1-3, pp. 79-88, 2006.

[10] J. H. Chang, A. V. Ellis, C. T. Yan, and C. H. Tung, "The electrochemical phenomena and kinetics of EDTA-copper wastewater reclamation by electrodeposition and ultrasound," Separation and Purification Technology, vol. 68, no. 2, pp. 216-221, 2009.

[11] C. C. Yang, "Recovery of heavy metals from spent Ni-Cd batteries by a potentiostatic electrodeposition technique," Journal of Power Sources, vol. 115, no. 2, pp. 352-359, 2003.

[12] J. G. G. A. Butts, Copper: The Science and Technology of the Metal, its Alloys and Compounds, vol. 122 of ACS Monograph, Reinhold, New York, NY, USA, 1960.

[13] T. N. Anderson, C. N. Wright, and K. J. Richards, "Important electrochemical aspects of electrowinning copper fiom acid leach solutions," in International Symposium on Hydrometallurgy, D. J. I. Evans and R. S. Shoemaker, Eds., vol. 127, p. 154, AIME, 1973.

[14] R. Winand, "Electrocrystallization of copper," Transactions of The Institution of Mining and Metallurgy C, vol. 84, pp. 67-75, 1975.

[15] D. W. Dew and C. V. Phillips, "The effect of Fe(II) and Fe(III) on the efficiency of copper electrowinning from dilute acid $\mathrm{Cu}(\mathrm{II})$ sulphate solutions with the chemelec cell. Part I. Cathodic and anodic polarisation studies," Hydrometallurgy, vol. 14, no. 3, pp. 331-349, 1985.
[16] A. Cooke, J. Chilton, and D. Fray, "Mass-transfer kinetics of the ferrous-ferric electrode process in copper sulphate elecrowinning electrolytes," Transactions of The Institution of Mining and Metallurgy C, vol. 98, 1990.

[17] S. Karthikeyan, A. Titus, A. Gnanamani, A. Mandal, and G. Sekaran, "Treatment of textile wastewater by homogeneous and heterogeneous Fenton oxidation processes," Desalination, vol. 281, pp. 438-445, 2011.

[18] G. Chen, "Electrochemical technologies in wastewater treatment," Separation and Purification Technology, vol. 38, no. 1, pp. 11-41, 2004.

[19] S. C. Das and P. G. Krishna, "Effect of Fe(III) during copper electrowinning at higher current density," International Journal of Mineral Processing, vol. 46, no. 1-2, pp. 91-105, 1996.

[20] D. M. Muir, "Basic principles of chloride hydrometallurgy," in Proceedings of the International Conference Chloride Metallurgy Practice and Theory of Chloride/Metal Interaction, E. Peek and G. van Weert, Eds., vol. 2, pp. 759-791, CIM, Montreal, Canada, 2002. 

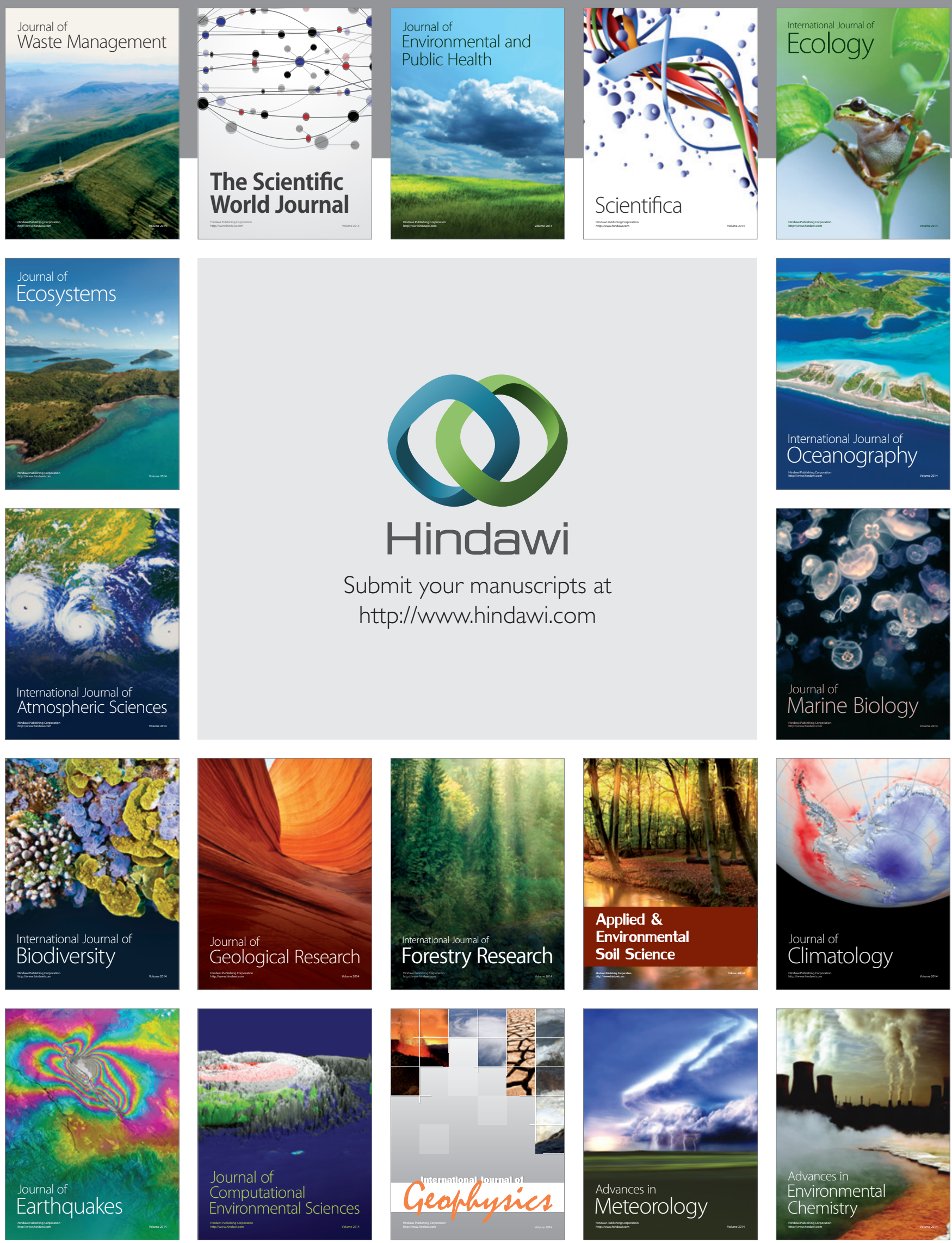